
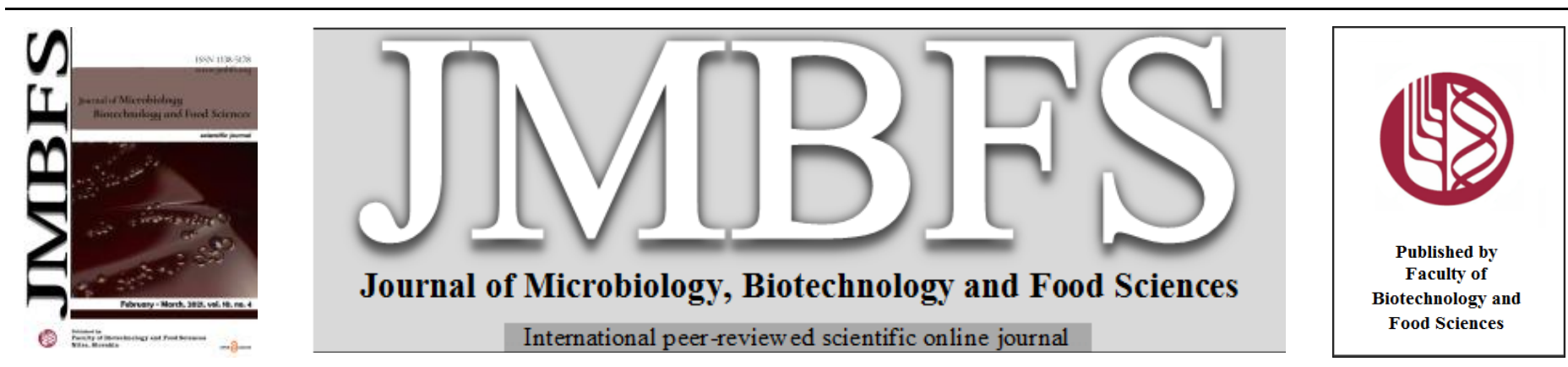

\title{
IDENTIFICATION OF FILAMENTOUS FUNGI IN TURKISH MOLD-RIPENED CHEESES AND SCREENING OF MYCOTOXIN GENES OF PENICILLIUM ROQUEFORTI ISOLATES
}

\author{
Hatice Ebrar Kirtil $*^{1}$, Banu Metin ${ }^{1}$, Muhammet Arici ${ }^{2}$ \\ Address(es): Hatice Ebrar Kirtil, M.Sc. \\ ${ }^{1}$ Department of Food Engineering, Faculty of Engineering and Natural Sciences, Istanbul Sabahattin Zaim University, Halkali Street 281, 34303 Istanbul, Turkey. \\ ${ }^{2}$ Department of Food Engineering, Faculty of Chemical and Metallurgical Engineering, Yildiz Technical University, Davutpasa, 34220 Istanbul, Turkey.
}

*Corresponding author: hatice.kirtil@izu.edu.tr

doi: 10.15414/jmbfs.2021.10.4.657-662

\section{ARTICLE INFO}

Received 11. 4. 2020

Revised 29. 10. 2020

Accepted 5. 11.2020

Published 1. 2. 2021

Regular article

OPEN $\partial_{\text {ACCESS }}$

\section{ABSTRACT}

Turkish mold-ripened cheese varieties are traditionally produced by spontaneous fungal growth during the ripening process in cellars or caves. In this study, fourty strains of filamentous fungi were isolated from mold-ripened cheeses of different regions. Internal transcribed spacer (ITS) sequencing identified the most common species as Penicillium roqueforti (52\%). The two key genes, roqA/rds and $m p a C$, involved in the biosynthesis of roquefortine $\mathrm{C}$ and mycophenolic acid, respectively, were screened by PCR. The presence of fragments of these genes in all $P$. roqueforti isolates indicates the potential of the isolates for production of these metabolites. Four selected strains of $P$. roqueforti produced roquefortine $\mathrm{C}$, but mycophenolic acid was detected in only two strains. Variability in the production of the metabolites might indicate the presence of polymorphisms outside of the region amplified or in other genes or their regulatory regions in the biosynthetic pathway.

Keywords: Mold-ripened cheeses, filamentous fungal diversity, P.roqueforti, roquefortine C, mycophenolic acid

\section{INTRODUCTION}

Mold-ripened cheese products are popular cheese types consumed worldwide. They are composed of two main groups: blue-veined cheeses, such as Roquefort, Danish Blue, Cabrales, Gorgonzola, and Stilton; and surface-ripened cheeses, including but not limited to Camembert-type soft cheeses and semi-hard ones, e. g., Tomme, Cantal, Tilsit and Ossau Iraty (Fox et al., 2016; Metin, 2018). Mold ripened cheese products are produced either by using fungal secondary starters, such as Penicillium roqueforti and Penicillium camemberti, or left for spontaneous fermentation in artisanal production facilities (Metin, 2018). Turkey also has traditional mold-ripened cheese varieties, most of which can be described as blue cheeses. The most famous of these are Erzurum Kuflu Civil and Karaman Divle Cave Tulum cheeses, which have geographical certification marks. Other varieties include but are not limited to Konya Kuflu (Green) cheese, mold-ripened Hatay Surk, Kup and Tomas (Cokelek, Serto, Dorak) cheeses (Çakmakçı, 2011; TPE, 2019). Most of these varieties are produced by spontaneous fermentation in caves, cellars, or in store-houses without using a mold starter.

Fungal secondary metabolites, including mycotoxins, are substances that are not vital for fungal growth but are believed to confer a competitive advantage to the producer fungus (Hymery et al., 2014). They are generally bioactive compounds. Some (e.g. agroclavines, isofumigaclavines, ochratoxins, citrinin) are harmful to human health due to their toxic properties. Others, such as andrastin A and mycophenolic acid are important for pharmaceutical industry due to antitumor, antibacterial, or immunosuppressive effects (Rojas-Aedo et al., 2017). Penicillium roqueforti, the principal fungal species of blue cheeses, is known to produce $\mathrm{PR}$ toxin, roquefortine $\mathrm{C}$ and $\mathrm{D}$, mycophenolic acid, isofumigaclavine $\mathrm{A}$ (roquefortine A), festuclavine, agroclavine, eremofortines, andrastins and citreo isocoumarin (Nielsen et al., 2006; O'Brien et al., 2006; Visagie et al., 2014; Fontaine et al., 2015; Del-Cid et al., 2016; Garcia-Estrada \& Martin, 2016; Gillot et al., 2017a). Roquefortine C, mycophenolic acid and PR toxin are the most commonly reported among these metabolites (Gillot $\boldsymbol{e t}$ al., 2017b; GarciaEstrada \& Martin, 2016). Although PR toxin is of great concern toxicologically, due to the amino acid composition of the cheese and the microaerophilic conditions, it is not stable in cheese and is reduced to PR imine that has lower toxicity or turn into other metabolites such as PR amide and PR acid (Scott \& Kanhere, 1979; Cheng et al., 2003; Dubey et al., 2018) Roquefortines have antibacterial activity against Gram-positive bacteria and can be useful in controlling the population of bacteria during the cheese ripening process (Frisvad et al., 2007; Perrone \& Susca, 2017). However, roquefortine C is a mycotoxin with a low level of neurotoxic and cytotoxic effects and its presence might create a health risk (Kosalkova et al., 2015; Garcia-Estrada \& Martin, 2016). Mycophenolic acid, on the other hand, has antimicrobial, antitumor, and antipsoriasis activities. Specifically, because of its immunosuppressive activity, it is used in the formulations of drugs used to prevent organ rejection in kidney, liver and heart transplant patients (Del-Cid $\boldsymbol{e t}$ al., 2016; Gillot et al., 2017a).

Fungal secondary metabolites are generally synthesized by the action of a group of enzymes, the genes of which are linked together in the genome and organized in clusters (Lind et al., 2017). Based on the chemical structure of the secondary metabolite, the clusters might harbor genes that code for a terpene synthase, a polyketide synthase or a nonribosomal peptide synthase (Brown et al., 2011). For example, roquefortine $\mathrm{C}$ is an indole alkaloid synthesized from precursor amino acids that are condensed by a non-ribosomal peptide synthetase coded by the $r d s /$ roqA gene (Garcia-Estrada \& Martin, 2016). In addition to $r d s /$ roq $A$, the roquefortine $\mathrm{C}$ biosynthesis gene cluster harbors $r d h / r o q R, r p t / r o q D$ and the residual pseudogene gmt/roqN. Rdh/roqR and $r p t /$ roqD are a cytochrome $\mathrm{P} 450$ oxidoreductase and a prenyl transferase, respectively. They have roles in later steps in roquefortine $\mathrm{D}$ and roquefortine $\mathrm{C}$ biosynthesis (Ali et al., 2013; Kosalkova et al., 2015; Garcia-Estrada \& Martin, 2016). Likewise, $P$. roqueforti has seven genes (mpaA, mpaB, mpaC, mpaDE, mpaF, mpaG, and $m p a H)$ in the gene cluster of mycophenolic acid biosynthesis (24.4 kbp) (Del-Cid et al., 2016; Garcia-Estrada \& Martin, 2016). Mycophenolic acid is an organic acid, and its backbone is formed as the first step in the biosynthetic pathway by the action of the putative polyketide synthase encoded by mpaC (Del-Cid $\boldsymbol{e t}$ al., 2016; Garcia-Estrada \& Martin, 2016).

Molecular methods show that secondary metabolite gene clusters can be polymorphic among isolates; single nucleotide polymorphisms (SNPs)/short indels, gene loss/gains, and entire cluster loss/gains can be observed, or the location of the cluster on the chromosome might differ (Lind et al., 2017). These kinds of polymorphisms were reported for the secondary metabolite gene clusters of several fungi, including Aspergillus fumigatus, Aspergillus flavus, Fusarium fujikuroi, and Cochliobolus carbonum, in addition to $P$. roqueforti (Ahn \& Walton, 1996; Chang et al., 2005; Wiemann et al., 2013; Chiara et al., 2015; Lind et al., 2017; Gillot et al., 2017a).

In this study, we aimed to identify the filamentous fungi isolated from traditional mold-ripened cheeses of Turkey by molecular methods. In addition, we screened $P$. roqueforti isolates for the presence of the roqA/rds and mpaC genes, the 
products of which play roles in the biosynthesis of roquefortine $\mathrm{C}$ and mycophenolic acid, respectively. This screening was performed to determine if whole-gene losses were present among the isolates. Selected $P$. roqueforti isolates were also analyzed by Q-TOF LC/MS for the production of roquefortine $\mathrm{C}$ and mycophenolic acid.

\section{MATERIAL AND METHODS}

\section{Cheese samples}

A total of 17 cheese samples including eleven Konya Kuflu Tulum (samples 1 11), three Divle Cave Tulum (samples 12, 13, 17) and three Erzurum Kuflu Civil (samples 14-16), were collected from local markets and were stored at $+4^{\circ} \mathrm{C}$ until the analysis.

\section{Mold isolation from cheese samples}

Ten $\mathrm{g}$ from each cheese sample was aseptically transferred to sterile bags and 90 $\mathrm{mL}$ of $0.1 \%$ peptone water was added. Then the mixture was homogenized for 2 min (Stomacher Blender SJIA-04C, China). Dilutions were prepared and inoculated on potato dextrose agar (PDA) plates. All plates were incubated at $25^{\circ} \mathrm{C}$ for 5 days. Twenty-two molds were isolated from Konya Kuflu Tulum, Divle Cave Tulum, and Erzurum Kuflu Civil cheeses. Another 18 molds previously isolated (from Cecil (Chechil) cheese from the Kars district, Tomas cheese from the Elazig-Bingol district, Surk cheese from the Hatay district, and Tulum cheese from the Mediterranean region) were also used in this study. In total, 40 mold isolates were purified on PDA (Florez \& Mayo, 2006; Çakmakçı et al., 2012; Fontaine et al., 2015).

To prepare stock cultures, purified isolates were grown on PDA at $25^{\circ} \mathrm{C}$ for 5 days. The mycelia collected were transferred with a sterile needle into cryo tubes containing $500 \mu \mathrm{L}$ of $40 \%$ sterile glycerol solution (Kosalkova et al., 2015). Culture stocks were kept at $-80^{\circ} \mathrm{C}$. For short-term storage, the prepared PDA agar slants were stored at $+4^{\circ} \mathrm{C}$ (Florez \& Mayo, 2006; Çakmakçı et al., 2012).

\section{Morphological examination}

Macro-morphological features of the isolates, such as colony colors, forms, and exudate production, were examined on PDA and malt extract agar (MEA) plates. For microscopic examination, the selected isolates were cultivated on PDA and incubated at $25^{\circ} \mathrm{C}$ for three days. Mycelium structures (coniophore, conidia, and branching type) were investigated on light microscope (Olympus BX53, DP27, Japan) by staining with lactophenol cotton blue (LPCB) and on a scanning electron microscope (SEM, Fei Quanta FEG250, USA) by zooming 2,500; 5,000; 10,000; and 20,000 times (Rosana et al., 2014).

\section{Isolation of genomic DNA}

Fungal DNA isolation was performed by phenol-chloroform-isoamyl alcoho (PCI) extraction after cell lysis (Florez \& Mayo, 2006; Umesha et al., 2016) First, the mycelia of the fungal cultures grown on plates were collected with a sterile needle and transferred to microcentrifuge tubes containing $450 \mu \mathrm{L}$ of $1 \mathrm{X}$ Tris-EDTA buffer. After gentle mixing to resuspend the mycelia in the buffer solution, $50 \mu \mathrm{L}$ of $10 \%$ SDS and $2 \mu \mathrm{L}$ proteinase $\mathrm{K}(1 \mathrm{mg} / \mathrm{mL})$ were added to the mixture, and the tubes were mixed well. Then, the mixture was incubated first at $37^{\circ} \mathrm{C}$ for $60 \mathrm{~min}$ and next at $65^{\circ} \mathrm{C}$ for $10 \mathrm{~min}$. Then, $500 \mu \mathrm{L}$ of PCI solution $(25: 24: 1)$ (Acros, USA) was added to the tubes and mixed well. After $5 \mathrm{~min}$ of incubation at room temperature $\left(25^{\circ} \mathrm{C}\right)$, the tubes were centrifuged at $12,000 \mathrm{rpm}$ at $4^{\circ} \mathrm{C}$ for $5 \mathrm{~min}$. The supernatant was transferred to new tubes and PCI extraction was repeated. After that, $50 \mu \mathrm{L}$ of $5 \mathrm{M}$ sodium acetate $(\mathrm{pH} 5.2)$ and 1 $\mathrm{mL}$ of isopropanol were added and the tubes were centrifuged at $10,000 \mathrm{rpm}$ for $5 \mathrm{~min}$. The supernatant was removed and the pellet was washed with $500 \mu \mathrm{L}$ of $70 \%$ ethanol. After centrifugation, the pellet was dried at $37^{\circ} \mathrm{C}$ for $5 \mathrm{~min}$ and resuspended in $100 \mu \mathrm{L}$ of $1 \mathrm{X}$ Tris-EDTA buffer ( $\mathrm{pH} 8.0)$. The quality of the DNA extracts was measured with a BioSpec Nano spectrophotometer (Shimadzu, Japan). DNA samples having an $\mathrm{OD}_{260} / \mathrm{OD}_{280}$ (optical density) value between 1.7-2.0 were considered acceptable for further use. DNA isolates were stored at $20^{\circ} \mathrm{C}$ (Florez \& Mayo, 2006; Florez et al., 2007).

\section{PCR amplification}

For identification purposes, internal transcribed spacer (ITS) regions was used The ITS region was amplified by using the forward ITS1 (5'TCCGTAGGTGAACCTGCGG-3') primer and the reverse ITS4 (5'TCCTCCGCTTATTGATATGC-3') primer (White et al., 1990). PCR mix (25 $\mu \mathrm{L}$ ) consisted of $12.5 \mu \mathrm{L} 2 \mathrm{X}$ PCR Master Mix ( $i$-Taq) solution (Intron, South Korea), $7.5 \mu \mathrm{L}$ of $\mathrm{dH}_{2} \mathrm{O}, 2 \mu \mathrm{L}$ of $12.5 \mathrm{mM}$ forward and $2 \mu \mathrm{L}$ of $12.5 \mathrm{mM}$ reverse primers, and $1 \mu \mathrm{L}(\sim 50 \mathrm{ng})$ of template DNA. For no-DNA control, water was used instead of DNA. PCR was carried out using a thermal cycler (BioRad, T100, USA) with the following conditions: initial denaturation at $94^{\circ} \mathrm{C}$ for $1 \mathrm{~min}, 34$ cycles of denaturation at $94^{\circ} \mathrm{C}$ for $30 \mathrm{sec}$, annealing at $52^{\circ} \mathrm{C}$ for $30 \mathrm{sec}$, extension at $72{ }^{\circ} \mathrm{C}$ for $1 \mathrm{~min}$, and a final extension at $72^{\circ} \mathrm{C}$ for $10 \mathrm{~min}$ was used (White $\boldsymbol{e t}$ al., 1990; Çakmakçı et al., 2012; Panelli et al., 2012).

For the detection of the mycotoxin genes of $P$. roqueforti isolates, the dipeptide synthetase gene, $r d s / r o q A$ (GenBank accession number: KP970559.1), which is involved in the production of roquefortine $\mathrm{C}$, and the polyketide synthase gene, mpaC (KU234530.1), which is responsible for the biosynthesis of mycophenolic acid were selected. Primers were designed by Primer 3 software using the $r d s / r o q A$ and $m p a C$ gene sequences (Untergasser et al., 2012). The $r d s / r o q A$ gene was amplified by PCR using the forward RoqAF (5'ACTACACCGCCATTGACTCC-3') and the reverse RoqAR (5'CTCAATCTCGTGCACCTCAA-3') primers. For the mpaC gene, a forward MpaCF (5'-TCTGTCAAGGCAGACTGGTG-3') primer and a reverse MpaCR (5'-TCGTCCGATAGCTCAGTGTG-3') primer were used. PCR conditions for $r d s /$ roqA and $m p a C$ were the same as for ITS PCR except that the annealing temperature was $50^{\circ} \mathrm{C}$ for $r d s / r o q A$ and $54^{\circ} \mathrm{C}$ for $m p a C$. Selected PCR products obtained were sequenced to confirm the specificity of the amplicons.

The PCR amplicons were electrophoresed on $1.2 \%$ agarose gel in $0.5 \mathrm{X}$ TrisBorate-EDTA buffer at $120 \mathrm{~V}$ for 90 min using OWL A2 gel electrophoresis system (Thermo Fisher Scientific, St. Louis, MO, USA) (Panelli et al., 2012; Çakmakçı et al., 2012). For electrophoresis, samples were mixed with $6 \mathrm{X}$ loading dye (Thermo Fisher Scientific) and loaded with 100 bp DNA ladder (Thermo Fisher Scientific). Visualization was performed using the Gel-Doc XR+ gel imaging system (Bio-Rad Laboratories, Hercules, CA, USA). The PCR products were purified with a Vivantis GF-1 PCR Clean-up Kit (Vivantis, Malaysia) according to manufacturer's instructions for sequencing purposes.

\section{Sequencing and phylogenetic analysis}

Sequencing of the PCR amplicons was performed by a commercial company (MedsanTek, Istanbul, Turkey) using BigDye ${ }^{\circledR}$ Direct Cycle Sequencing Kit (Thermo Fisher Scientific) and Applied Biosystems 24-capillary 3500xL Genetic Analyzer (Thermo Fisher Scientific). From the NCBI BLAST database, the identity of the isolates was determined with $100 \%$ sequence identity. Sequence chromatograms were visualized using CLC Main Workbench 7 (Qiagen, Germany). Phylogenetic trees were generated by MEGA X software using an alignment produced by ClustalW (Kumar et al., 2018). The sequences of reference (type) strains used in alignment were as follows: Penicillium roqueforti CBS 221.30 (NR_103621), Penicillium chrysogenum CBS 306.48 (NR_077145), Penicillium corylophilum NRRL 802 (NR_121236), Penicillium biforme CBS 297.48 (NR 138325), Penicillium camemberti CBS 299.48 (AB479314), Penicillium crustosum FRR 1669 (NR_077153), Penicillium rubens CBS 129667 (NR_111815) and Penicillium spinulosum FRR 1750 (NR_077158). The evolutionary history was inferred by using the Maximum Likelihood method and the Kimura 2-parameter model, the best-fit model determined using MEGA X with 1000 bootstrap replicates (Kimura, 1980). Initial tree(s) for the heuristic search were obtained automatically by applying Neighbor-Join and BioNJ algorithms to a matrix of pairwise distances estimated using the Maximum Composite Likelihood (MCL) approach, and then selecting the topology with superior log likelihood value. The tree is drawn to scale, with branch lengths measured in the number of substitutions per site.

\section{Secondary metabolite production of selected $P$. roqueforti isolates}

Mycotoxin production levels of four randomly selected Penicillium roqueforti isolates were determined on YES medium (Yeast Extract Sucrose Agar) with QTOF LC/MS (Agilent 6530 Accurate-Mass Quadrupole Time-of-flight, USA). First, the isolates were inoculated on PDA plates and incubated at $25^{\circ} \mathrm{C}$ for 5 days. Then, they were cultivated on YES medium and incubated in the dark at $25^{\circ} \mathrm{C}$ for 14 days (Frisvad \& Samson, 2004; Gillot et al., 2017b). Afterwards the YES cultures were homogenized for 1 min using an Ultraturrax T18 (IKA, Heidelberg, Germany). Then, $4 \mathrm{~g}$ of the sample was transferred into a $100-\mathrm{mL}$ bottle, and $25 \mathrm{~mL}$ of acetonitrile containing $0.1 \%$ formic acid was added. The mixtures were vortexed for $30 \mathrm{~s}$ and kept in an ultrasonic water bath (Selecta, Spain) for $15 \mathrm{~min}$. Then, the samples were centrifuged at $5000 \mathrm{~g}$ for $10 \mathrm{~min}$ at $4^{\circ} \mathrm{C}$. The supernatant was collected and stored at $-20^{\circ} \mathrm{C}$ until analysis (Gillot $\boldsymbol{e t}$ al., 2017b).

For chromatography, the extracts were filtered through a $0.2 \mu \mathrm{m}$ PTFE membrane syringe $4 \mathrm{~mm}$ filter and $1 \mathrm{~mL}$ of each of the samples were transferred to vials. The extracts were analyzed for the presence of roquefortine $\mathrm{C}$ and mycophenolic acid by an Q-TOF LC/MS system with ESI+ (Electrospray Ionization) Scan mode using the method developed by Gillot et al. (2017b), with two replicates. In HPLC, a ZORBAX Extend-C-18 (2.1 x $50 \mathrm{~mm}$ and $1.8 \mu \mathrm{m}$, 600 bar) column was used. The starting temperature of the column was $35^{\circ} \mathrm{C}$, and the mobile phase flow rate was $0.3 \mathrm{~mL} / \mathrm{min}$. As mobile phases, solvent A (Milli$\mathrm{Q}$ water $+0.1 \%$ LC/MS grade formic acid $(\mathrm{v} / \mathrm{v})+0.1 \%$ ammonium formate $(\mathrm{v} / \mathrm{v}))$ and solvent B (100\% LC/MS grade acetonitrile) were used. Solvent B was maintained at $10 \%$ for $4 \mathrm{~min}$, and a gradient flow of $10-100 \%$ was provided for 36 min. Eventually, solvent B was hold at $100 \%$ for 10 min. Mass spectrometer conditions were set as follows: Ion range from 100 to $1000 \mathrm{~m} / \mathrm{z}$; capillary 
voltage, $4 \mathrm{kV}$; source temperature, $325^{\circ} \mathrm{C}$; drying gas, $12 \mathrm{~L} / \mathrm{min}$, and nebulizer pressure, $50 \mathrm{psig}$.

\section{RESULTS}

Species diversity of the Turkish mold-ripened cheeses

For genotypic identification, ITS1-5.8S-ITS2 rRNA (ITS) region was used. ITS sequencing detected 6 different species, namely, P. roqueforti (52\%, 21 isolates) Penicillium corylophilum (14\%, 6 isolates), Penicillium biforme (13\%, 5 isolates), Penicillium crustosum ( $8 \%, 3$ isolates), Penicillium spinulosum ( $8 \%, 3$ isolates) and Penicillium rubens (5\%, 2 isolates) (Table 1). Among these, $P$. roqueforti was the most prominent species with 21 isolates. The phylogenetic tree based on the ITS region is given in Figure 1. The phylogenetic analysis grouped the isolates into 6 different branches according to the differences in their ITS region. Phylogenetic analysis showed that ITS sequence diversity was sufficient to discriminate between closely related species, such as $P$. rubens from $P$ chrysogenum, or $P$. biforme from $P$. camemberti. The cheese isolates were grouped into well-supported (>97\%) clades together with the type strain of each species verifying their identity.

Conidiophore branching patterns were used in taxonomy in the past, but are stil considered important in identification (Visagie $\boldsymbol{e t}$ al., 2014). The isolates randomly chosen from each species were visualized by scanning electron microscopy (SEM) (Figure 2). Conidiophore patterns varies from simple, such as the monoverticillate pattern of $P$. spinulosum (Figure $2 \mathrm{H}$ ) having phialides directly connected to the stipe and the biverticillate pattern of $P$. corylophilum (Figure $2 \mathrm{G}$ ), which has metulae between the stipe and the phialides to more complex patterns (Houbraken et al., 2014). P. roqueforti (Figure 2A, 2B, and 2C), P. crustosum (Figure 2D) and P. biforme (Figure 2E) have terverticillate patterns including one more branch between the stipe and the metulae. In addition, the warty structure of the stipes and the branches were noted as described previously (Frisvad \& Samson, 2004). Penicillium rubens (Figure 2F) has quaterverticillate structure having an extra branch beyond the terverticillate pattern (Frisvad \& Samson, 2004).

Table 1 Identification of Penicillium strains isolated from Turkish traditional mold-ripened cheeses

\begin{tabular}{|c|c|c|}
\hline Isolate Code & ITS Sequencing & Isolation Source \\
\hline 1Y5D* & Penicillium roqueforti & $\begin{array}{c}\text { Konya Moldy Tulum } \\
\text { Cheese }\end{array}$ \\
\hline $2 Y 5 F$ & Penicillium roqueforti & $\begin{array}{c}\text { Konya Moldy Tulum } \\
\text { Cheese }\end{array}$ \\
\hline 3Y5A & Penicillium roqueforti & $\begin{array}{c}\text { Konya Moldy Tulum } \\
\text { Cheese }\end{array}$ \\
\hline 4Y5A & Penicillium roqueforti & $\begin{array}{l}\text { Konya Moldy Tulum } \\
\text { Cheese }\end{array}$ \\
\hline $4 Y 5 B *$ & Penicillium roqueforti & $\begin{array}{c}\text { Konya Moldy Tulum } \\
\text { Cheese }\end{array}$ \\
\hline 4Y5D* & Penicillium crustosum & $\begin{array}{c}\text { Konya Moldy Tulum } \\
\text { Cheese }\end{array}$ \\
\hline 5B & Penicillium biforme & Other** \\
\hline $5 Y 5 A$ & Penicillium roqueforti & $\begin{array}{c}\text { Konya Moldy Tulum } \\
\text { Cheese }\end{array}$ \\
\hline $5 \mathrm{Y5C}$ & Penicillium crustosum & $\begin{array}{l}\text { Konya Moldy Tulum } \\
\text { Cheese }\end{array}$ \\
\hline 6 & Penicillium corylophilum & Other \\
\hline $6 Y 5 B$ & Penicillium roqueforti & $\begin{array}{l}\text { Konya Moldy Tulum } \\
\text { Cheese }\end{array}$ \\
\hline $6 Y 5 C$ & Penicillium roqueforti & $\begin{array}{c}\text { Konya Moldy Tulum } \\
\text { Cheese }\end{array}$ \\
\hline $6 Y 5 E$ & Penicillium roqueforti & $\begin{array}{c}\text { Konya Moldy Tulum } \\
\text { Cheese }\end{array}$ \\
\hline $7 \mathrm{Y5E}$ & Penicillium roqueforti & $\begin{array}{c}\text { Konya Moldy Tulum } \\
\text { Cheese }\end{array}$ \\
\hline $8 Y 5 B$ & Penicillium roqueforti & $\begin{array}{c}\text { Konya Moldy Tulum } \\
\text { Cheese }\end{array}$ \\
\hline 9Y5B & Penicillium roqueforti & $\begin{array}{c}\text { Konya Moldy Tulum } \\
\text { Cheese }\end{array}$ \\
\hline 10D & Penicillium spinulosum & Other \\
\hline $10 Y 5 C$ & Penicillium roqueforti & $\begin{array}{c}\text { Konya Moldy Tulum } \\
\text { Cheese }\end{array}$ \\
\hline $11 \mathrm{C}$ & Penicillium biforme & Other \\
\hline 11Y5B & Penicillium roqueforti & $\begin{array}{c}\text { Konya Moldy Tulum } \\
\text { Cheese }\end{array}$ \\
\hline 12D & Penicillium biforme & Other \\
\hline $12 F^{*}$ & Penicillium roqueforti & Other \\
\hline 12Y5D & Penicillium crustosum & $\begin{array}{c}\text { Divle-Cave Moldy Tulum } \\
\text { Cheese }\end{array}$ \\
\hline
\end{tabular}

\begin{tabular}{lcc}
\hline 13B* & Penicillium corylophilum & $\begin{array}{c}\text { Other } \\
\text { 13Y6E* }\end{array}$ \\
14Y5B & Penicillium rubens & $\begin{array}{c}\text { Divle-Cave Moldy Tulum } \\
\text { Cheese } \\
\text { Erzurum Moldy Civil } \\
\text { Cheese }\end{array}$ \\
16Y4B & Penicillium roqueforti & $\begin{array}{c}\text { Erzurum Moldy Civil } \\
\text { Cheese }\end{array}$ \\
17Y5C & Penicillium roqueforti & $\begin{array}{c}\text { De } \\
\text { Divle-Cave Moldy Tulum } \\
\text { Cheese }\end{array}$ \\
17Y5D* & Penicillium roqueforti & Divle-Cave Moldy Tulum \\
21C & Penicillium roqueforti & Cheese \\
22E & Penicillium corylophilum & Other \\
23A & Penicillium biforme & Other \\
23B & Penicillium corylophilum & Other \\
23C & Penicillium corylophilum & Other \\
25C & Penicillium roqueforti & Other \\
25D & Penicillium corylophilum & Other \\
29D & Penicillium rubens & Other \\
30C* & Penicillium roqueforti & Other \\
30D & Penicillium spinulosum & Other \\
31A* & Penicillium spinulosum & Other \\
\hline
\end{tabular}

*Species selected to be analyzed by SEM.

**Other: Previously isolated molds from Chechil Cheese from the Kars district, Tomas Cheese from the Elazig-Bingol district,

Surk Cheese from the Hatay district, and Tulum cheese from the Mediterranean region.
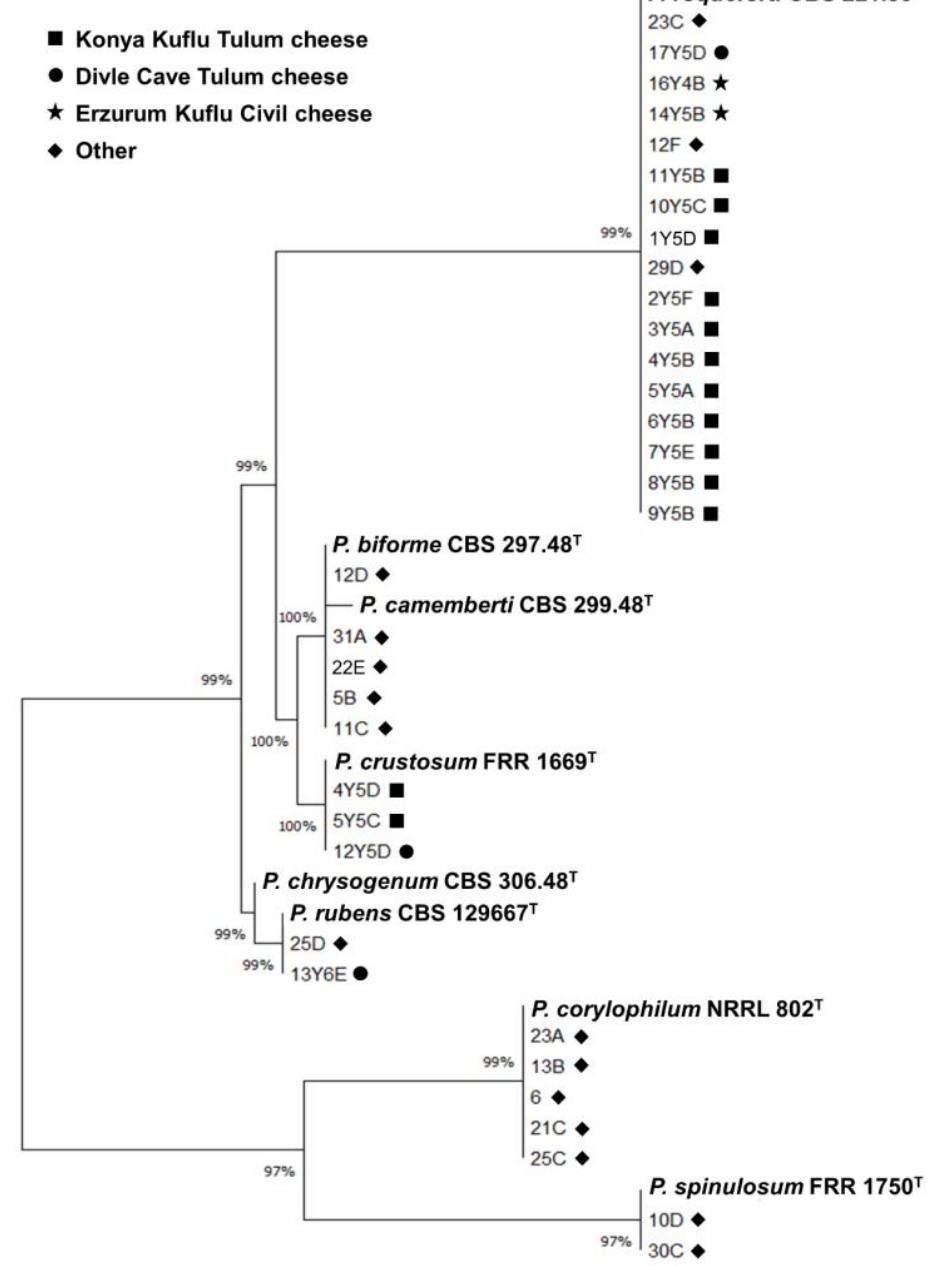

0.010

Figure 1 Phylogenetic tree of the isolates generated by the Maximum Likelihood approach using the ITS1-5.8S-ITS2 rRNA (ITS) region. The tree with the highes $\log$ likelihood $(-831.52)$ is shown. In total, there were 380 positions in the final dataset. Isolates with identical sequences obtained from the same cheese sample were excluded from the analysis (4Y5A, 6Y5C, 6Y5E, 17Y5C, 23B, and 30D). 


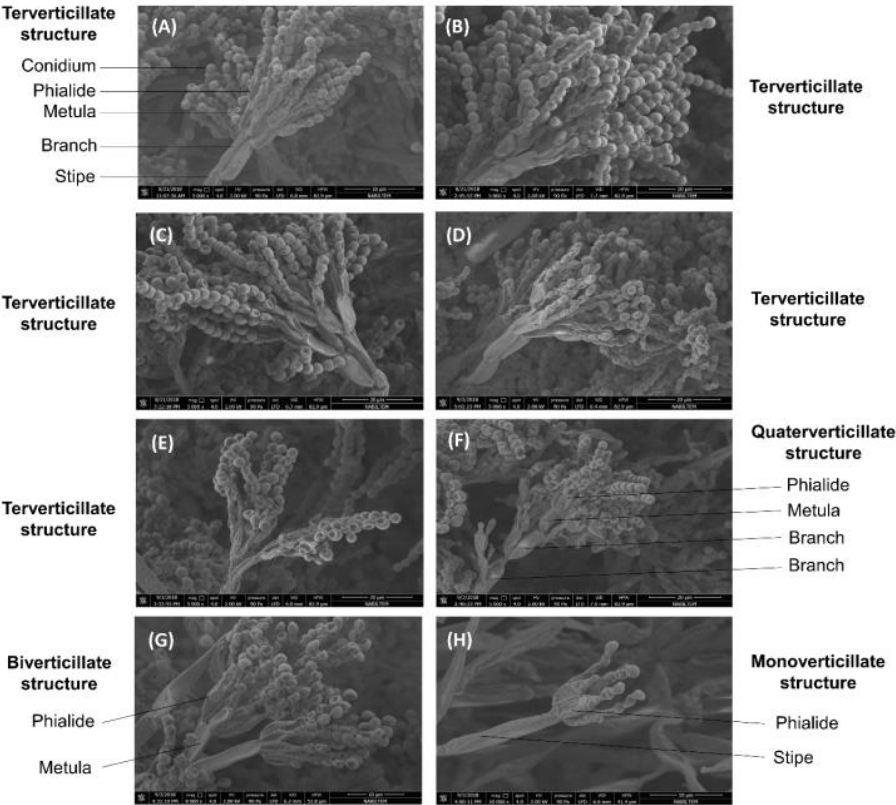

Figure 2 SEM Images of $P$. roqueforti 12F (A), 1Y5D (B) and 4Y5B (C), $P$. crustosum 4Y5D (D), P. biforme 31A (E) and P. rubens 13Y6E (F), P.corylophilum 13B (G) and P.spinulosum 30C (H) isolates.

PCR screening indicates the presence of $r d s / r o q A$ and $m p a C$ genes in all $P$. roqueforti isolates

PCR screening showed that all $P$. roqueforti isolates (21 strains), harbored 360bp and 590-bp products of the $r d s / r o q A$ and $m p a C$ genes, respectively. The PCR products of two isolates were sequenced to confirm the specificity of the PCR reaction. The $r d s / r o q A$ and $m p a C$ genes are responsible for roquefortine $\mathrm{C}$ and mycophenolic acid production, respectively. An agarose gel image of the PCR products of four representative isolates is shown in Figure 3.

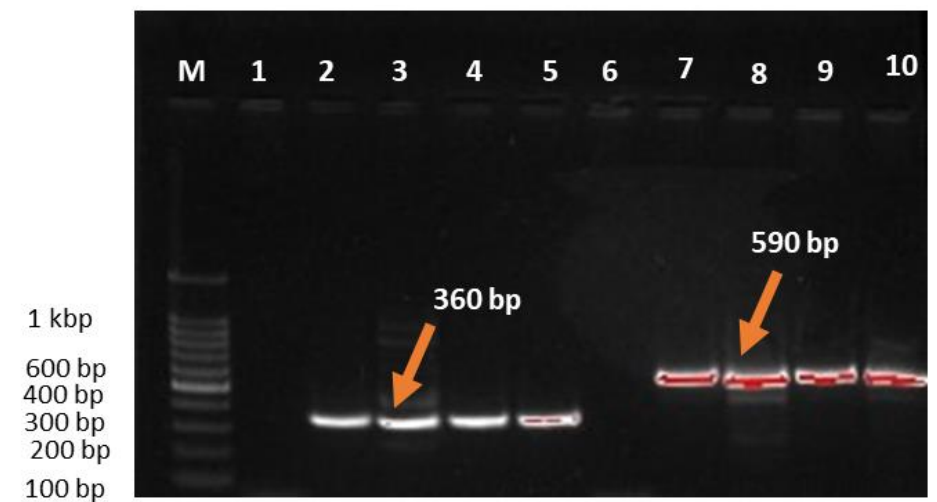

Figure 3 Agarose gel image of PCR products of mycotoxin genes; M: DNA marker (100 bp-1kbp), 1: roqA negative control, 2: 1Y5D,

3: 12F, 4: 4Y5B, 5: 17Y5D, 6: mpaC negative control, 7: 1Y5D, 8: 12F, 9 4Y5B, 10: 17Y5D

Determination of the secondary metabolites of selected Penicillium roqueforti isolates by Q-TOF LC/MS

While roquefortine $\mathrm{C}$ was determined in the all extracts of the four selected $P$ roqueforti isolates, mycophenolic acid could only be detected in two (1Y5D and 17Y5D) (Figure 4).
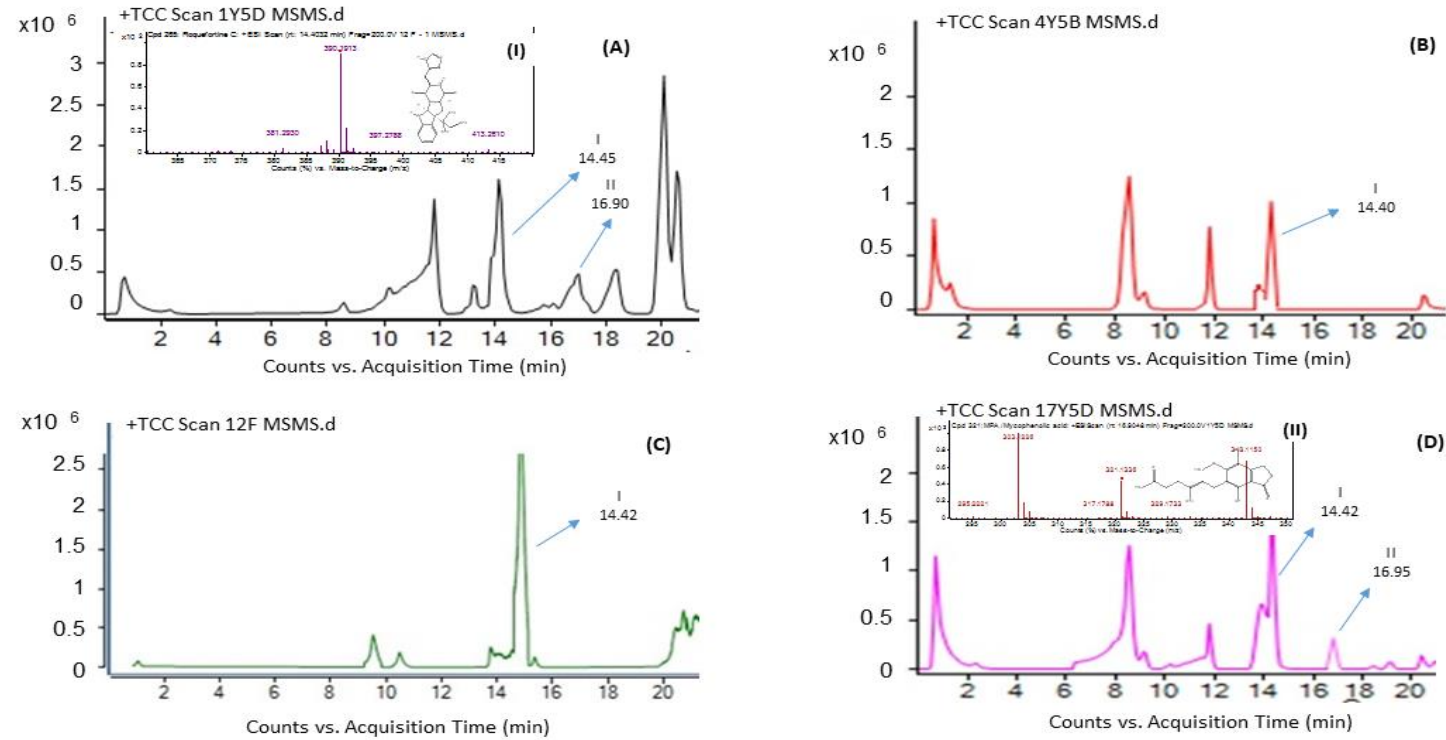

Figure 4 Total chemical chromatograms (TCC) of the extracts of the $P$. roqueforti isolates $1 \mathrm{Y} 5 \mathrm{D}(\mathrm{A}), 4 \mathrm{Y} 5 \mathrm{~B}(\mathrm{~B}), 12 \mathrm{~F}(\mathrm{C})$ and 17Y5D (D). Peaks of identified metabolites are shown as I: Roquefortine C, II: Mycophenolic acid. Roquefortine C $\left(\mathrm{C}_{22} \mathrm{H}_{23} \mathrm{~N}_{5} \mathrm{O}_{2}\right)$ was determined in ESI+ mode with the addition of $[\mathrm{H}+]$ ion in the mass spectrum (B1) for all four isolates with a retention time of 14.40-14.45 min. Similarly, mycophenolic acid $\left(\mathrm{C}_{17} \mathrm{H}_{20} \mathrm{O}_{6}\right)(\mathrm{A} 1)$ was determined in ESI+ mode (retention time of 16.90-16.95), but in only two of the isolates (1Y5D and 17Y5D).

\section{DISCUSSION}

In blue cheeses worldwide, P.roqueforti is the dominant species (Florez \& Mayo, 2006; Gillot et al., 2017b; Ropars et al., 2017; Metin, 2018). Studies conducted on Turkish mold-ripened cheeses demonstrated similar findings, but they involve mostly morphological identification techniques. For example, in moldy Civil cheese, 165 of 186 isolates were identified as $P$. roqueforti, and the remaining 21 isolates were identified as Penicillium spp. (Cakmakçı $\boldsymbol{e t}$ al., 2012). In a study conducted in Konya and its vicinity, 140 mold-ripened cheese samples were examined; $86 \%$ of the isolates were identified at the genus level as Penicillium, and the remaining 12\% were identified as Aspergillus (Özkalp \&
Durak, 1998). In another study, 158 mold isolates were identified using morphological characteristics, and $70 \%$ of these were described as Penicillium species harboring $P$. commune, $P$. roqueforti, $P$. verrucosum, $P$. expansum, and $P$. chrysogenum (Hayaloglu \& Kirbag, 2007). In another study, 21 mold-ripened cheese samples from Konya, Mersin, Nevsehir, and Nigde were analyzed, and eight different species were identified morphologically. $P$. roqueforti was the most commonly isolated mold, followed by $P$. chrysogenum (Sağdıç et al., 2008). Twelve of the 16 mold species isolated from the moldy Tulum cheese sold in Erzurum and its vicinity were identified based on morphology as $P$. roquefort (Erdoğan et al., 2003). In a study analyzing the microbial diversity of Divle cave cheese, among the 101 filamentous fungi isolated, Penicillium was the dominant 
genus and the most predominant species were $P$. polonicum, $P$. biforme, $P$ roqueforti, and $P$. chrysogenum (Öztürkoğlu-Budak et al., 2016). Similar to these findings, we identified all 40 strains isolated from various Turkish moldripened cheeses as Penicillium; the most common species was $P$. roqueforti. In our study we aimed to determine roquefortine $C$ and mycophenolic acid production of four selected $P$. roqueforti isolates on YES medium. While we detected roquefortine $\mathrm{C}$ in all four isolates using Q-TOF LC/MS, we could observe mycophenolic acid production in only two of them. In previous studies, mycophenolic acid production level was observed to be lower than that of roquefortine C (Gillot $\boldsymbol{e t} \boldsymbol{a l}$., 2017b); therefore we may not be able reach the detection limit of mycophenolic acid. Another reason might be that the strains selected were not mycophenolic acid producers. Consistent with that, previous studies show that mycotoxin production varied among different isolates of $P$. roqueforti. For example, Larsen et al. (2002) indicated the presence of roquefortine $\mathrm{A}$ (isofumigaclavine $\mathrm{A}$ ) and roquefortine $\mathrm{C}$; however, mycophenolic acid or PR toxin could not be detected. In another study (Nielsen et al., 2006), while roquefortine $\mathrm{C}$ was found in all 9 isolates, mycophenolic acid was detected in eight of them. O'Brien et al. (2006) analyzed 79 P. roqueforti isolates, and roquefortine $\mathrm{C}$ and mycophenolic acid production were detected in $96 \%$ and $85 \%$ of the isolates, respectively. In another study, while roquefortine $\mathrm{C}$ was detected in $96 \%$ of the isolates, mycophenolic acid was found in $87 \%$ of 55 P. roqueforti isolates (Gillot et al., 2017b).

The variability in the production of fungal secondary metabolites among strains of the same species might be directly linked to polymorphisms in the gene cluster involved in the production of the secondary metabolite or to the regulatory network directing the expression of this cluster. For example, recent studies have shown that secondary metabolite gene clusters are highly divergent because of some variations such as single nucleotide polymorphisms (SNPs), gene and gene cluster gains and losses, and idiomorph and genomic location polymorphisms (Lind et al., 2017). For instance, four out of 66 isolates of Aspergillus fumigatus lacked the non-ribosomal peptide synthetase (NRPS) gene in addition to two other genes in a secondary metabolite cluster (Lind et al., 2017). In addition, some strains completely lack whole clusters of certain secondary metabolites. (Lind et al., 2017). A similar study on non-aflatoxinogenic Aspergillus flavus isolates shows that these isolates have different types of deletions in the aflatoxin gene cluster (Chang et al., 2005). For example, while some of these strains are devoid of nearly half of the aflatoxin cluster, others completely lack the cluster. Similar findings were also reported for Fusarium fujikuroi and Cochliobolus carbonum (Chiara et al., 2015; Wiemann et al., 2013; Ahn \& Walton, 1996) Similar to these studies, Gillot et al. (2017a) demonstrated that 19 out of $55 P$. roqueforti isolates have a 174-bp deletion in their mpaC gene, coding for the polyketide synthase involved in mycophenolic acid synthesis, and this deletion was in correlation with no or limited production of mycophenolic acid. In our study, we show that all $P$. roqueforti isolates harbor the $r d s / r o q A$ and $m p a C$ genes detected by PCR, and no major change (such as large indels) is present within the regions amplified. Our amplification region does not span the 174-bp region detected previously; therefore, polymorphisms can be present in this region. In addition, there might be other polymorphisms in the genes that can only be detected by sequencing. In addition, possible gain/loss events in the other genes in the clusters can only be detected by screening of the other genes as well, or ideally, by whole genome sequencing (WGS).

Regulatory pathways are also important in secondary metabolite production. For example, a global regulator, putative methyltransferase LaeA has been shown to affect secondary metabolic gene cluster expression in many fungi, including Penicillium species (Zhang et al., 2016). The study by Soliman et al. (2015) shows that, although a number of Penicillium species studied all had an idh gene responsible for patulin production, transcription of $i d h$ was only observed in $P$. expansum. Similarly, Bogs et al. (2006) showed that a polyketide synthase gene involved in ochratoxin A biosynthesis is present in both $P$. nordicum and $P$ nalgiovense. It is transcribed only in $P$. nordicum, which shows the importance of regulatory factors. Variation of secondary metabolite production would also be linked to regulatory networks. WGS or several longer PCR reactions to retrieve the entire cluster would also shed light on the mutations that might be present in the regulatory regions of the genes.

\section{CONCLUSION}

In this study, we isolated and molecularly identified the filamentous fungi of traditional Turkish mold-ripened cheeses. fourty fungal strains included six different Penicillium species with the most prevalent being $P$. roqueforti (52\%), concordant with the previous studies. Other species consist of $P$. rubens, $P$. biforme, $P$. crustosum, $P$. corylophilum, and $P$. spinulosum. $P$. roqueforti isolates were screened for the presence of the roqA/rds and mpaC genes, the products of which play roles in the biosynthesis of roquefortine $\mathrm{C}$ and mycophenolic acid respectively. All $P$. roqueforti isolates were observed by PCR to harbor the $r d s / r o q A$ and $m p a C$ gene fragments. This showed the absence of large deletion events in the corresponding genes and the potential of the isolates to produce these metabolites. When four selected $P$. roqueforti isolates were analyzed by QTOF LC/MS, all were observed to produce roquefortine C. Meanwhile mycophenolic acid was detected in two isolates. Variability in the secondary metabolite production of the isolates might be related to various kinds of polymorphisms in the biosynthetic pathway genes. Future studies might involve metabolite detection of a larger number of isolates. In addition, WGS could be helpful in detecting all kinds of variations in secondary metabolite biosynthetic gene clusters. Determination of the effect of these metabolites on cheese production would be helpful in the search for a fungal starter culture that can be used in the production of healthier products.

\section{REFERENCES}

Ali, H., Ries, M.I., Nijland, J.G., Lankhorst, P.P., Hankemeier, T., Bovenberg, R.A.L., et al. (2013). A branched biosynthetic pathway is involved in production of roquefortine and related compounds in Penicillium chrysogenum. PLoS One, 8 , e65328. https://doi.org/10.1371/journal.pone.0065328

Bogs, C., Battilani, P. \& Geisen, R. (2006). Development of a molecular detection and differentiation system for ochratoxin A producing Penicillium species and its application to analyse the occurence of Penicillium nordicum in cured meats. International Journal of Food Microbiology, 107, 39-47. https://doi.org/10.1016/j.ijfoodmicro.2005.08.010

Brown, D.W., Butchko, R.A.E. \& Proctor, R.H. (2011). Identification of genes and gene clusters involved in mycotoxin synthesis. In S. De Saeger (Ed.), Determining mycotoxins and mycotoxigenic fungi in food and feed (pp. 333-348) Cambridge, UK: Woodhead Publishing.

Chang, P.K, Horn, B.W. \& Dorner, J.W. (2005). Sequence breakpoints in the aflatoxin biosynthesis gene cluster and flanking regions in nonaflatoxigenic Aspergillus flavus isolates. Fungal Genetics and Biology, 42, 914-23. https://doi.org/10.1016/j.fgb.2005.07.004

Chiara, M., Fanelli, F., Mule, G., Logrieco, A.F., Pesole, G., Leslie, J.F., et al (2015). Genome sequencing of multiple isolates highlights subtelomeric genomic diversity within Fusarium fujikuroi. Genome Biology and Evolution, 7, 3062 3069. https://doi.org/10.1093/gbe/evv198

Çakmakçı, S., (2011). Türkiye Peynirleri. In A.A. Hayaloğlu \& B. Özer (Ed.) Peynir Biliminin Temelleri. İzmir, Turkey: Sidas Medya Ltd. Sti.

Çakmakçı, S., Çetin, B., Gürses, M., Dağdemir, E. \& Hayaloğlu, A.A. (2012) Morphological, molecular and mycotoxigenic identification of dominant filamentous fungi from Moldy Civil Cheese. Journal of Food Protection, 75, 2045-2049. https://doi.org/10.4315/0362-028X.JFP-12-107

Del-Cid, A., Gil-Duran, C., Vaca, I., Rojas-Aedo, J.F., Garcia-Rico, R.O., et al. (2016). Identification and functional analysis of the mycophenolic acid gene cluster of Penicillium roqueforti. PLoS One, 11, e0147047. https://doi.org/10.1371/journal.pone.0147047

Dubey, M.K., Aamir, M., Kaushik, M.S., Khare, S., Meena,, M., Singh, S., et al (2018). PR toxin - biosynthesis, genetic regulation, toxicological potential, prevention and control measures: overview and challenges. Frontiers in Pharmacology, 9, 288. https://doi.org/10.3389/fphar.2018.00288

Erdoğan, A., Gurses, M. \& Sert, S. (2003). Isolation of moulds capable of producing mycotoxins from blue mouldy Tulum Cheeses produced in Turkey. International Journal of Food Microbiology, 85, 83-85. https://doi.org/10.1016/S0168-1605(02)00485-3

Florez, A.B. \& Mayo, B. (2006). Microbial diversity and succession during the manufacture and ripening of traditional, Spanish, blue-veined Cabrales cheese, as determined by PCR-DGGE. International Journal of Food Microbiology, 110 165-171. https://doi.org/10.1016/j.ijfoodmicro.2006.04.016

Florez, A.B., Alvarez-Martin, P., Lopez-Diaz, T.M. \& Mayo, B. (2007) Morphotypic and molecular identificaton of filamentous fungi from Spanish blue-veined Cabrales cheese, and typing of Penicillium roqueforti and Geotrichum candidum isolates. International Dairy Journal, 17, 350-357. https://doi.org/10.1016/j.idairyj.2006.04.002

Fontaine, K., Hymery, N., Lacroix, M.Z., Puel, S., Puel, O., Rigalma, K., et al (2015). Influence of intraspesific variability and abiotic factors mycotoxin production in Penicillium roqueforti. International Journal of Food Microbiology, 215, 187-193. https://doi.org/10.1016/j.ijfoodmicro.2015.07.021 Fox, P.F., Guinee, T.P., Cogan, T.M. \& McSweeney, P.L.H. (2016) Fundamentals of cheese science (2rd edn., Chapt. 3), New York, USA: Springer. Frisvad, C.F. \& Samson, R.A. (2004). Polyphasic taxonomy of Penicillium subgenus Penicillium: A guide to identification of food and air-borne terverticillate Penicillia and their mycotoxins. Studies in Mycology, 49, 1-174.

Frisvad, J.C., Thrane, U. \& Samson, R.A. (2007). Mycotoxin producers. In J. Dijksterhuis \& R.A. Samson (Ed.), Food mycology: A multifaceted aproach to fungi and food (pp.135-159). New York, USA: CRC press.

Garcia-Estrada, C. \& Martin, J.F. (2016). Biosynthetic gene clusters for relevant secondary metabolites produced by Penicillium roqueforti in blue cheeses Applied Microbiology and Biotechnology, 100, 8303-8313. https://doi.org/10.1007/s00253-016-7788-x

Gillot, G., Jany, J.L., Dominguez-Santos, R., Poirier, E., Debaets, S., Hidalgo, P.I., et al. (2017a). Genetic basis for mycophenolic acid production and straindependent production variability in Penicillium roqueforti. Food Microbiology, 62, 239-250. https://doi.org/10.1016/j.fm.2016.10.013

Gillot, G., Jany, J.C., Poirier, E., Maillard, M.B., Debaets, S., Thierry, A., et al (2017b). Functional diversity within the Penicillium roqueforti species 
International Journal of Food Microbiology, 241, 141-150 https://doi.org/10.1016/j.ijfoodmicro.2016.10.001

Houbraken, J., Visagie, C.M., Meijer, M., Frisvad, J.C., Busby, P.E., Pitt, J.I., et al. (2014). A taxonomic and phylogenetic revision of Penicillium section Aspergilloides. Studies in Mycology, 78, 373-451. https://doi.org/10.1016/j.simyco.2014.09.002

Hymery, N., Vasseur, V., Coton, M., Mounier, J., Jany, J.L., Barbier, G. et al. (2014). Filamentous fungi and mycotoxins in cheese: A review. Comprehensive Reviews in Food Science and Food Safety, 13, 437-456. https://doi.org/10.1111/1541-4337.12069

Kimura M. (1980). A simple method for estimating evolutionary rate of base substitutions through comparative studies of nucleotide sequences. Journal of Molecular Evolution, 16, 111-120. https://doi.org/10.1007/bf01731581

Kosalkova, K., Dominguez-Santos, R., Coton, M., Coton, E., Garcia-Estrada, C., Liras, P. et al. (2015). A natural short pathway synthesizes roquefortine $\mathrm{C}$ but not meleagrin in three different Penicillium roqueforti strains. Applied Microbiology and Biotechnology, 99, 7601-7612. https://doi.org/10.1007/s00253-015-6676-0

Kumar, S., Stecher, G., Li, M., Knyaz, C. \& Tamura, K. (2018). MEGA X Molecular Evolutionary Genetics Analysis across computing platforms Molecular Biology and Evolution, 35, 1547-1549. https://doi.org/10.1093/molbev/msy096

Larsen, T.O., Gareis, M. \& Frisvad, J.C. (2002). Cell cytotoxicity and mycotoxin and secondary metabolite production by common Penicillia on cheese agar Journal of Agricultural and Food Chemistry, 50, 6148-6152. https://doi.org/10.1021/jf020453i

Lind, A.L., Wisecaver, J.H., Lameiras, C., Wiemann, P., Palmer, J.M., Keller, N.P., et al. (2017). Drivers of the genetic diversity in the secondary metabolic gene clusters within a fungal species, PLoS Biology, 15, e2003583. https://doi.org/10.1371/journal.pbio.2003583

Metin, B. (2018). Filamentous fungi in cheese production. In S., ÖztürkoğluBudak \& H.C., Akal (Ed.), Microbial cultures and enzymes in dairy technology (pp. 257-275), Hershey PA, USA: IGI Global.

Nielsen, K.F., Sumarah, M.W., Frisvad, J.C. \& Miller, J.D. (2006). Production of metabolites from the Penicillium roqueforti complex. Journal of Agricultural and Food Chemistry, 54, 3756-3763. https://doi.org/10.1021/jf060114f

O’Brien, M., Nielsen, K.F., O'Kiely, P., Forristal, P.D., Fuller, H.T. \& Frisvad, J.C. (2006). Mycotoxins and other secondary metabolites produced in vitro by Penicillium paneum Frisvad, Penicillium roqueforti Thom isolated from baled grass silage in Ireland. Journal of Agricultural and Food Chemistry, 54, 9268 9276. https://doi.org/10.1021/if0621018

Özkalp, B. \& Durak, Y. (1998). Konya ve civarı küflü peynirlerinde küf florasının araştırılması. Tübitak Turkish Journal of Biology, 22, 341-346.

Öztürkoğlu-Budak, S., Figge, M.R., Houbraken, J. \& Vries, R.P. (2016). The diversity and evolution of microbiota in traditional Turkish Divle Cave cheese during ripening, International Dairy Journal, 58, 50-53, https://doi.org/10.1016/j.idairyj.2015.09.011

Panelli, S., Buffoni, J.N., Bonacina, C. \& Feligini, M. (2012). Identification of moulds from the Taleggio cheese environment by the use of DNA barcodes. Food Control, 28, 385-391. https://doi.org/10.1016/j.foodcont.2012.05.022

Perrone, G. \& Susca, A. (2017). Penicillium species and their associated mycotoxins. In A. Moretti \& A. Susca (Ed.), Mycotoxigenic fungi: Methods and protocols (pp. 107-119). New York, USA: Humana Press Springer Protocols. https://doi.org/10.1007/978-1-4939-6707-0 5

Rojas-Aedo, J.F., Gil-Duran, C., Del-Cid, A., Valdes, N., Alamos, P., Vaca, I., et al. (2017). The biosynthetic gene cluster for andrastin A in Penicillium roqueforti. Frontiers in Microbiology, 5, 8, 813. https://doi.org/10.3389/fmicb.2017.00813

Rosana, Y., Matsuzawa, T., Gonoi, T. \& Karuniawati, A., (2014). Modified slide culture method for faster and easier identification of dermatophytes. Microbiology Indonesia, 8, 135-139.

Sağdıç, O., Özçelik, S., Şimşek, B. \& Özdemir, C. (2008). Geleneksel yöntemle üretilen küflü peynirlerin mikrobiyolojik nitelikleri ve küf florası. (pp. 709-712), 21-23 May, 10th Food Congress, Erzurum, Turkey.

Scott, P.M. \& Kanhere, S.R. (1979). Instability of PR toxin in blue cheese, Journal of Association of Official Analytical Chemists, 62, 141-7. https://doi.org/10.1093/jaoac/62.1.141

Soliman, S., Li, X.Z., Shao, S., Behar, M., Svircev, A.M., Tsao, R. et al. (2015) Potential mycotoxin contamination risks of apple products associated with fungal flora of apple core. Food Control, 47, 585-591. https://doi.org/10.1016/i.foodcont.2014.07.060

Türk Patent Enstitüsü (TPE), (2019). "Geographical Registered List", http://www.turkpatent.gov.tr/TURKPATENT/geographicalRegisteredList/, Last Accessed Date: 11.04.2020

Umesha, S., Manukumar, H.M. \& Raghava, S. (2016). A rapid method for isolation of genomic DNA from food-borne fungal pathogens. 3 Biotech, 6, 123132. https://doi.org/10.1007/s13205-016-0436-4

Untergasser, A., Cutcutache, I., Koressaar, T., Ye, J., Faircloth, B.C., Remm, M. et al. (2012). Primer3-new capabilities and interfaces. Nucleic Acids Research 40, e115. https://doi.org/10.1093/nar/gks596
Visagie, C.M., Houbraken, J., Frisvad, J.C., Hong, S.B., Klaassen, C.H.W., Perrone, G., et al. (2014). Identification and nomenclature of the genus Penicillium. Studies in Mycology, 78, 343-371. https://doi.org/10.1016/j.simyco.2014.09.001

Wiemann, P, Sieber, C.M., on Bargen, K.W., Studt, L., Niehaus, E.M. et al (2013). Deciphering the cryptic genome: Genome-wide analyses of the rice pathogen Fusarium fujikuroi reveal complex regulation of secondary metabolism and novel metabolites. PLoS Pathogens, 9, e1003475. https://doi.org/10.1371/journal.ppat.1003475

White, T.J., Bruns, T., Lee, S. \& Taylor, J. (1990). Amplification and direct sequencing of fungal ribosomal RNA genes for phylogenetics. PCR Protocols: A Guide to Methods and Applications, 38, 315-322. http://dx.doi.org/10.1016/B978-0-12-372180-8.50042-1

Zhang, X., Zhu, Y., Bao, L., Gao, L., Yao, G., Li, Y., et al. (2016). Putative methyltransferase LaeA and transcription factor CreA are necessary for proper asexual development and controlling secondary metabolic gene cluster expression. Fungal Genetics and Biology, 94, 32-46. https://doi.org/10.1016/j.fgb.2016.07.004 